\title{
Response of the Coral Associated Nitrogen Fixing Bacteria Toward Elevated Water Temperature
}

\author{
Leomir Diaz \\ Institute of Biology, University of the Philippines, Diliman Quezon City, Philippines
}

\section{Email address:}

diazleomir@gmail.com

\section{To cite this article:}

Leomir Diaz. Response of the Coral Associated Nitrogen Fixing Bacteria Toward Elevated Water Temperature. Journal of Water Resources and Ocean Science. Vol. 6, No. 6, 2017, pp. 98-109. doi: 10.11648/j.wros.20170606.14

Received: October 9, 2017; Accepted: November 3, 2017; Published: November 29, 2017

\begin{abstract}
Coral reefs are among the most biologically diverse and economically important ecosystem on the planet. Despite the importance, reef habitat is being under threat from human exploitation, and its most serious stressor is increasing seawater temperature, an aftermath of global warming phenomenon. The increasing seawater temperature causes bleaching, diseases and insufficiency of nutrients of corals. Despite being surrounded by ocean waters were nutrient are in short supply, the reef ecosystem is a significant source of new nitrogen. Biological nitrogen fixation is a significant internal source of marine organism. The growth of all organism lies on the availability of mineral nutrients particularly of nitrogen $\left(\mathrm{N}_{2}\right)$. Approximately $80 \%$ of atmosphere is made of nitrogen, however, $\mathrm{N}_{2}$ can only be available for use by organism unless it undergoes a process of nitrogen fixation. In this aspect, related literature on biological nitrogen fixation seems sparse especially on the effects of increasing seawater temperature, a well-known contributing factor of coral bleaching. In this study, an investigation was conducted on nitrogen fixing bacterial communities associated in the coral Acropora digitifera, exploring its responses towards elevated water temperature. The study shows that exposure to high temperature causes a drastic change in the community of nitrogen fixing bacteria which are abundant in coral mucus. These changes, is correlated with the shift in the metabolic function in coral holobiont, thus, affecting both health and resiliency of corals. Overall, the finding highlights the impact of elevated seawater temperature on the nitrogen fixing bacterial composition and its diversity as well as its effects of this on host metabolism.
\end{abstract}

Keywords: Nitrogen Fixing Bacteria, Coral Mucus, Elevated Water Temperature, Coral Health

\section{Introduction}

Nitrogen $(\mathrm{N})$ is the building block in all life forms $[6,80]$. It is vital element for organism life and survival. Prior to organisms usage of nitrogen, it undergoes biological $\mathrm{N}_{2}$ fixation carried out by prokaryotes which includes the diverse group of bacteria commonly called diazotrophs [40, $80,86,87]$. The ecological niches of diazotrophs is largely limited to the open ocean oligotrophic gyres were $\mathrm{N}$ availability is low and of high light intensities and $\mathrm{O}_{2}$ concentration [35, 80]. Nitrogen is regarded as the most limiting element for biological productivity in the open sea $[6,25,35,80]$. Recent studies on the phylogenetic diversity and distribution of nifH gene, the functional gene which encodes the dinitrogenase iron protein, reveals that in marine environments, nitrogen fixing microorganism vents to highly productive shelf areas including the coral holobiont $[16,53$,

\section{7, 86].}

Recognized as a major contributor of newly produced Nitrogen into the oceans, shallow coral reefs habitat are aids a huge fraction of total benthic $\mathrm{N}_{2}$ fixation to a global scale $[55,62,80]$. These array of micro-organism was measured from various reef surface including carbonate sediments, [7, 82], algal dominated reef crest, [29, 48, 49], mucus and tissue of living corals [44], coral rubbles and coral skeleton [48, 49, 82]. Notably, the condition of these fix nitrogen varies considerably, as most coral use nitrogen mainly for growth and maintenance $[68,69,70]$. However, coral reefs is highly vulnerable to multiple disturbances such as global warming which results to increase of sea water temperature $[23,27$, $34,64,80]$.

Increasing seawater temperature causes thermal stress 
pressure which leads alteration of the physiology of reef organism [30, 31, 39], as well as of coral associated microorganism [58].

Corals secret mucus $[12,13]$. The chemical nature and quantity of mucus changes when corals are stressed [68, 69]. As a result, changes in the mucus environment damage the structure and membership of bacterial community [14, 71, 70]. Microorganisms are the fastest to respond towards disturbances [24, 25, 38]. Given that their responses are often nonlinear, they provide near real-time trajectories for coral reefs $[3,80]$.

Geared with the desire to attain a comprehensive knowledge and understanding on the underlying mechanism and interactions within the holobiont framework and the responses of corals to environmental change such as ocean warming, this study focused on how elevated water temperature affects the association of diazotrophic community with the scleractinian coral, Acropora digitifera. Specifically, the study concentrates on mucus-associated nitrogen fixing bacteria and its responses upon exposure to elevated water temperature. Also, to determine the functional role of the bacterial community, comparison on coral surface mucus between healthy and thermally stressed coral was made.

\section{Methods}

\subsection{Coral Materials}

Colonies of $A$. digitifera corals were collected at Caniogan Island ( $16^{\circ} 17$ ' 28.6" N, $120^{\circ} 00^{\prime} 44.2$ " E) Anda Reef complex, Pangasinan, Philippines. In-situ coral mucus was also collected to profile naturally occurring bacterial community. The coral was then transported with care in the Bolinao Marine Laboratory hatchery facility. Coral colonies was cut into nubbins using a wire cutter at about 2 to 3 inches long and attached to reef plugs using epoxy. Coral nubbins were acclimated for almost a month to insure recovery of wounds during cutting and to adapt into the hatchery environment in preparation for experimental heat stress. The hatchery tank was maintained in an ambient average temperature of $28^{\circ} \mathrm{C}, \mathrm{pH}$ of 8.14 (Mettler Tolido $\mathrm{pH}$ meter) and salinity of $33.13 \mathrm{ppt}$ (Atago-refractometer) in a flow through filtered sea water.

\subsection{Heat Stress}

Acclimated $A$. digitifera coral nubbins underwent heat stress by exposing to $32 \pm 1^{\circ} \mathrm{C}$ temperature as treatment and $27 \pm 1^{\circ} \mathrm{C}$ temperature as control for 10 days. Control tanks were maintain representing the cold month of the year (December to February) based on regular monitoring by the Bolinao Marine Laboratory. The set-up were conducted in a $12 \mathrm{~h} \mathrm{light/dark} \mathrm{cycle} \mathrm{with} \mathrm{irradiance} \mathrm{of} 14 \mu \mathrm{mol} \mathrm{m} \mathrm{m}^{-2} \mathrm{~s}^{-1}$. A low irradiance was used to reduce the potential contribution of high light intensity to the coral stress response. The coral nubbins were randomly distributed into each water conditions to avoid any possible bias of intercolony variability. The experimental system comprised of a $40 \mathrm{~L}$ tanks plumed into flowing sand-filtered seawater with constant aeration. All tanks were operated into a closed system air-conditioned room with humidity of $25^{\circ} \mathrm{C}$. Seawater temperature was manipulated with submersible thermostat heaters with additional submersible pump for equal distribution of heat into the tank. The water temperature in the tank was monitored using temperature probes (Labquip Temp (Labquest 2); Vernier software and Tech, Model-LQ2-LE) and recorded throughout the experiment using submersible water temperature data loggers (HOBOware pro. Onset, Pocasset, MA, USA). Throughout the course of the experiment, the state of the photosynthetic apparatus of the coral fragments was monitored, using a diving pulse-amplitude-modulated (PAM) fluorometer (Walz). PAM readings were taken from all coral fragments in the experimental and control tanks. Coral nubbins were collected in triplicate.

\subsection{DNA Extraction}

Individual coral fragments were rinsed in membrane filtered seawater (FSW) and sealed in a $50 \mathrm{ml}$ tube for 3 minutes to collect mucus secretions [41, 58]. DNA was extracted from $400 \mu \mathrm{l}$ of mucus using a modified cetyltrimethylammonium bromide (CTAB) method. Briefly, samples were mixed with CTAB extraction buffer $[100 \mathrm{mM}$ TrisCl, pH 8.0, 20mM EDTA, 2\% CTAB, $1.4 \mathrm{M} \mathrm{NaCl}$, $2.5 \mathrm{mg} / \mathrm{ml}$ lysozyme] and incubated at $37^{\circ} \mathrm{C}$ for $40 \mathrm{mins}$. After addition of $0.2 \% \quad \beta$-mercaptoethanol and $0.1 \mathrm{mg} / \mathrm{ml}$ proteinase $\mathrm{K}$, samples were then incubated at $60^{\circ} \mathrm{C}$ for $1 \mathrm{hr}$ followed by chloroform fractionation and isopropanol precipitation [83]. The DNA pellet was washed with $70 \%$ ethanol and dried at room temperature. The DNA was dissolved in $1 \mathrm{x}$ TE buffer and stored at $-20^{\circ} \mathrm{C}$.

\subsection{PCR Amplification}

A 359bp fragment of the nifH gene was amplified using the nested PCR approach [87]. Briefly, to amplify the nifH fragment, $1 \mu \mathrm{l}$ template DNA was added to a first PCR mixture containing $1 \mathrm{X}$ PCR buffer, $4.0 \mathrm{mM} \mathrm{MgCl}_{2}, 0.2 \mathrm{mM}$ $\mathrm{dNTP}$, 40ng $\mu \mathrm{l}^{-1}$ bovine serum albumin, 2.5 units Taq polymerase, and $10 \mu \mathrm{M}$ each of nifH3 and nifH4 primers. PCR cycles consisted of an initial heating step of 3 min at $94^{\circ} \mathrm{C}$, followed by 28 cycles of $94^{\circ} \mathrm{C}$ for $45 \mathrm{~s}, 57^{\circ} \mathrm{C}$ for $45 \mathrm{~s}$, and $72^{\circ} \mathrm{C}$ for $1 \mathrm{~min}$, followed by a final extension for $10 \mathrm{~min}$ at $72^{\circ} \mathrm{C} .1 \mathrm{ul}$ of the PCR product was subjected to a second round of PCR, identical to the first but with primers nifHI and nifH2. The nifH amplification products were separated by electrophoresis through $2.0 \%$ agarose gels and visualized with Sybr gold stain.

\subsection{Denaturing Gradient Gel Electrophoresis (DGGE)}

PCR amplification for DGGE was performed in a BioRad T100 thermal cycler using the bacterial 16S rRNA primers 357F-GC and 518R [60]. The PCR cycles consist of an initial heating step for $3 \mathrm{~min}$ at $94^{\circ} \mathrm{C}, 10$ cycles of $94^{\circ} \mathrm{C}$ for $1 \mathrm{~min}$, 
$65^{\circ} \mathrm{C}$ for $1 \mathrm{~min}, 72^{\circ} \mathrm{C}$ for $2 \mathrm{~min}$ with annealing temperature decreased by $1^{\circ} \mathrm{C}$ per cycle, followed by 28 cycles consisting of $94^{\circ} \mathrm{C}$ for $1 \mathrm{~min}, 55^{\circ} \mathrm{C} 1 \mathrm{~min}$, and $72^{\circ} \mathrm{C}$ for $2 \mathrm{~min}$, and a final extension for $10 \mathrm{~min}$ at $72^{\circ} \mathrm{C}$. The PCR products were loaded into a 30-60\% linear gradient of urea and formamide with $8 \%$ acrylamide. Gels were run in $1 \mathrm{X}$ TAE at $60 \mathrm{~V}$ for 16 hours at $60^{\circ} \mathrm{C}$ in a DGGE apparatus (C.B.S. Scientific, DGGE-2001). After electrophoresis, the gel was stained for 30 minutes with SYBR Gold nucleic acid stain in $1 \mathrm{x}$ TAE buffer, rinsed and photographed with a Nikon Camera (Nikon Digital Camera D5100). Distinct bands were excised from the gel and placed in $30 \mu 1$ nuclease free water overnight to diffuse the DNA. The eluted DNA was re-amplified for direct sequencing using the same primers as for DGGE but without the GC clamp. PCR cycles for re-amplification include an initial heating step for $3 \mathrm{~min}$ at $94^{\circ} \mathrm{C}$, followed by 35 cycles consisting of $94^{\circ} \mathrm{C}$ for $1 \mathrm{~min}, 55^{\circ} \mathrm{C}$ for $1 \mathrm{~min}, 72^{\circ} \mathrm{C}$ for $2 \mathrm{~min}$ followed by a final extension for $5 \mathrm{~min}$ at $72^{\circ} \mathrm{C}$. $16 \mathrm{~S}$ rRNA V3 PCR products were sequenced using dye terminator sequencing (BigDye Terminator v3.1 cycle) at FirstBase Laboratory, Malaysia. ImageJ was used to analyze DGGE banding patterns. Heirarchical clustering analysis of DGGE profiles was implemented in R using pvclust (Version 2.0-0, 2015) with unbiased p-values.

\section{6. nifH Gene Cloning and Sequencing}

nifH PCR products were cloned using the TOPO-TA cloning kit (Invitrogen) guided by the manufacturer instructions. Shortly, Amplified nifH from mucus samples were ligated into the TOPO-TA cloning vector. Inserts were transformed into the TOP 10 competent Escherichia coli cells. Transformation were plated on a Luria-Bertani (LB) media containing $50 \mu \mathrm{g} / \mathrm{ml}$ ampicilin, $50 \mu \mathrm{g} / \mathrm{ml}$ kanamycin and $40 \mathrm{mg} / \mathrm{ml} \mathrm{X}$-gal. Positive clones were selected by blue and white screening. Fifty white colonies of each mucus samples (Control $\left(27^{\circ} \mathrm{C}\right)$, Treated $\left(32^{\circ} \mathrm{C}\right)$, In-situ) were picked. The nifH insert was amplified using M13 forward and M13 reverse primers. PCR products from nifH clones were purified and sequenced using dye terminator sequencing (Big Dye Terminator v3.1 cycle) at First Base Laboratory, Malaysia.

\subsection{Data Analysis}

Obtained nifH sequences were trimmed and clean-up before sequence alignment using CLC sequence viewer 6.8.1 (CLC bio A/S; www.clcbio.com) and was refined manually by visual inspection before structural analysis. Sequences were translated into operational protein units (OPUs) using the Expasy translate tool (http://web.expasy.org/translate). Phylogenetic affiliation of the nif $H$ genes were determined by alignment to the nitrogenase nifH gene sequence database (http://www.css.cornell.edu/faculty/buckley/nifh.htm) and to NCBI non-redundant database (www.ncbi.nlm.nih.gov) using the BLASTn algorithm. Diversity parameters such as Shannon [75] and Simpson [78], as well as richness estimators (ACE and CHAO 1) of the nifH gene for each mucus samples were generated in MOTHUR [72, 73, 74].

\section{Results}

\subsection{Coral Physiology}

The coral fragments of $A$. digitifera survived collection, recovery, acclimatization and experimentation without exhibiting any visual signs of stress in the form of bleaching after 10 days of exposure to constant level of elevated temperature. In addition, comparable $\mathrm{Fv} / \mathrm{Fm}$ values were observed between readings from freshly collected colonies and coral fragments during the acclimatization period (Figure 1). Fluorescence measurements are used to assess the physiological state of the coral photosynthetic symbiont. These values measure the kinetics of fluorescence rise and decay in the light-harvesting antenna of thylakoid membrane, thus querying various aspects of the state of the photosystem under different environmental conditions. A slight but significant decline in $\mathrm{Fv} / \mathrm{Fm}$ was observed after 10 days of exposure to elevated temperature relative to the controls.

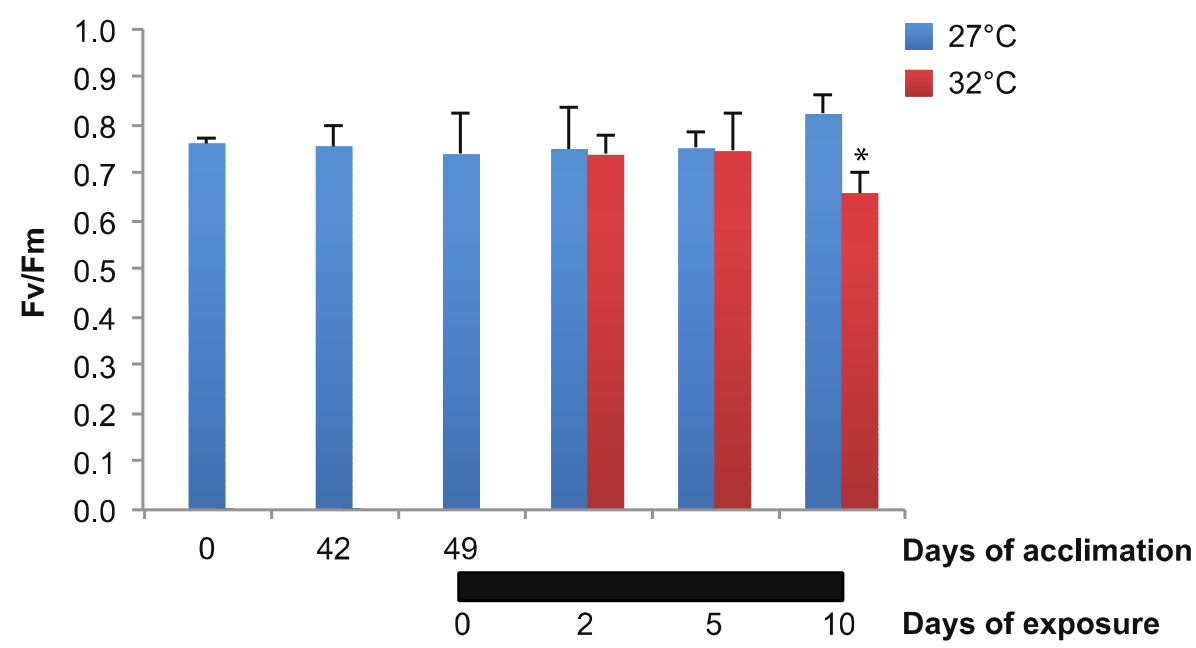

Figure 1. Maximum dark-adapted $F v / F m$ values for A. digitifera during acclimation and upon exposure to different temperature regimes. Asterisk indicates a Student's t-test p-value $<0.001$. 


\subsection{Shifts in Microbial Community in Response to Thermal Stress}

Denaturing gradient gel electrophoresis (DGGE) was initially used to examine the bacterial community composition of the corals exposed to $27 \pm 1^{\circ} \mathrm{C}$ temperature and $32 \pm 1{ }^{\circ} \mathrm{C}$ temperature as treatments. DGGE pattern comparison (Figure 3 ) showed that bacterial communities are different between coral mucus and tissue fractions and that the coral microbiota is vastly different from that of the seawater within the experimental tanks. Prolonged exposure to increased temperature resulted in the most obvious changes in the DGGE pattern for the mucus samples while tissue and seawater communities appeared to be the same. DGGE profile analysis was able to distinguish between the different coral fractions, as well as between treated and control samples (Figure 4). On the other hand, the abundance of bacteria associated with both the mucus and tissue of corals shows no change upon prolonged exposure to elevated water temperature as measured by DAPI-stained cell counting (Figure 2). However, it should be noted that these counts are only rough estimates of the number of bacterial cells. More accurate counts will be obtained with the use of bacteria specific probes.
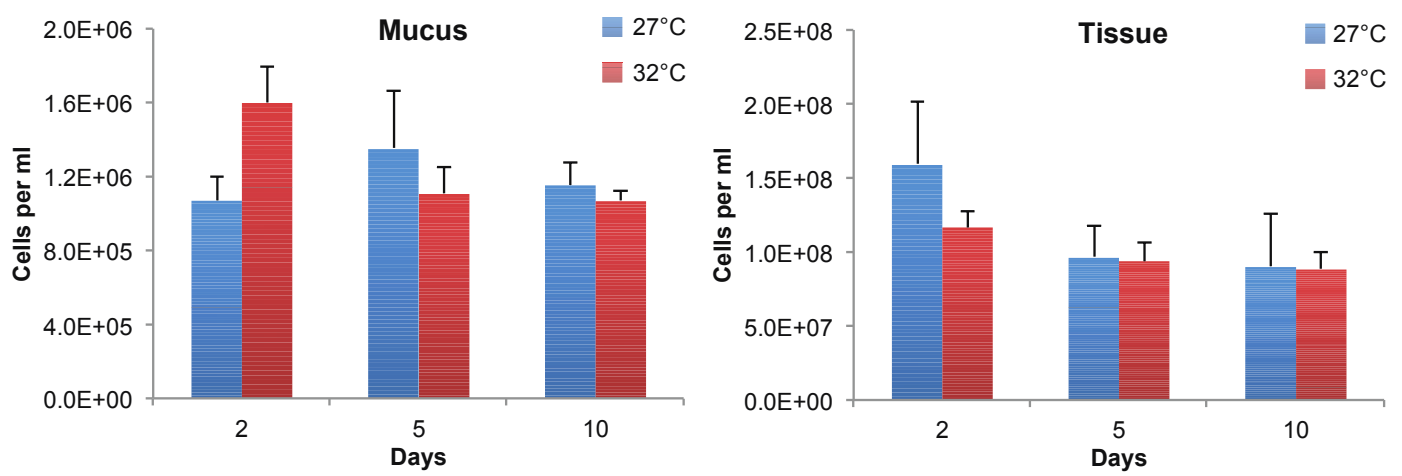

Figure 2. Bacterial abundance in mucus and tissue from corals exposed to elevated temperature relative to controls at ambient temperature. Bacterial abundance was determined by counting DAPI-stained samples under an epifluorescence microscope.

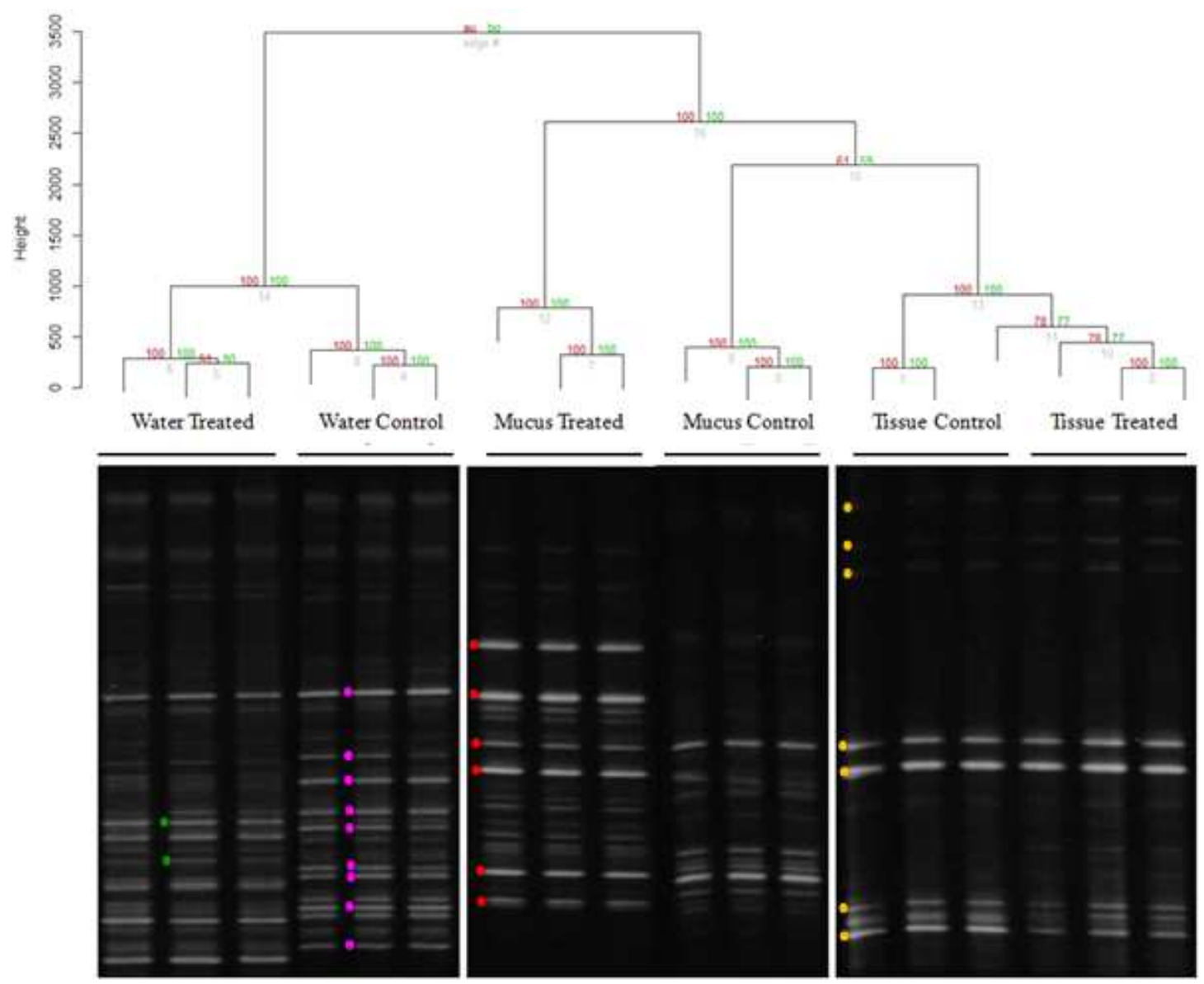




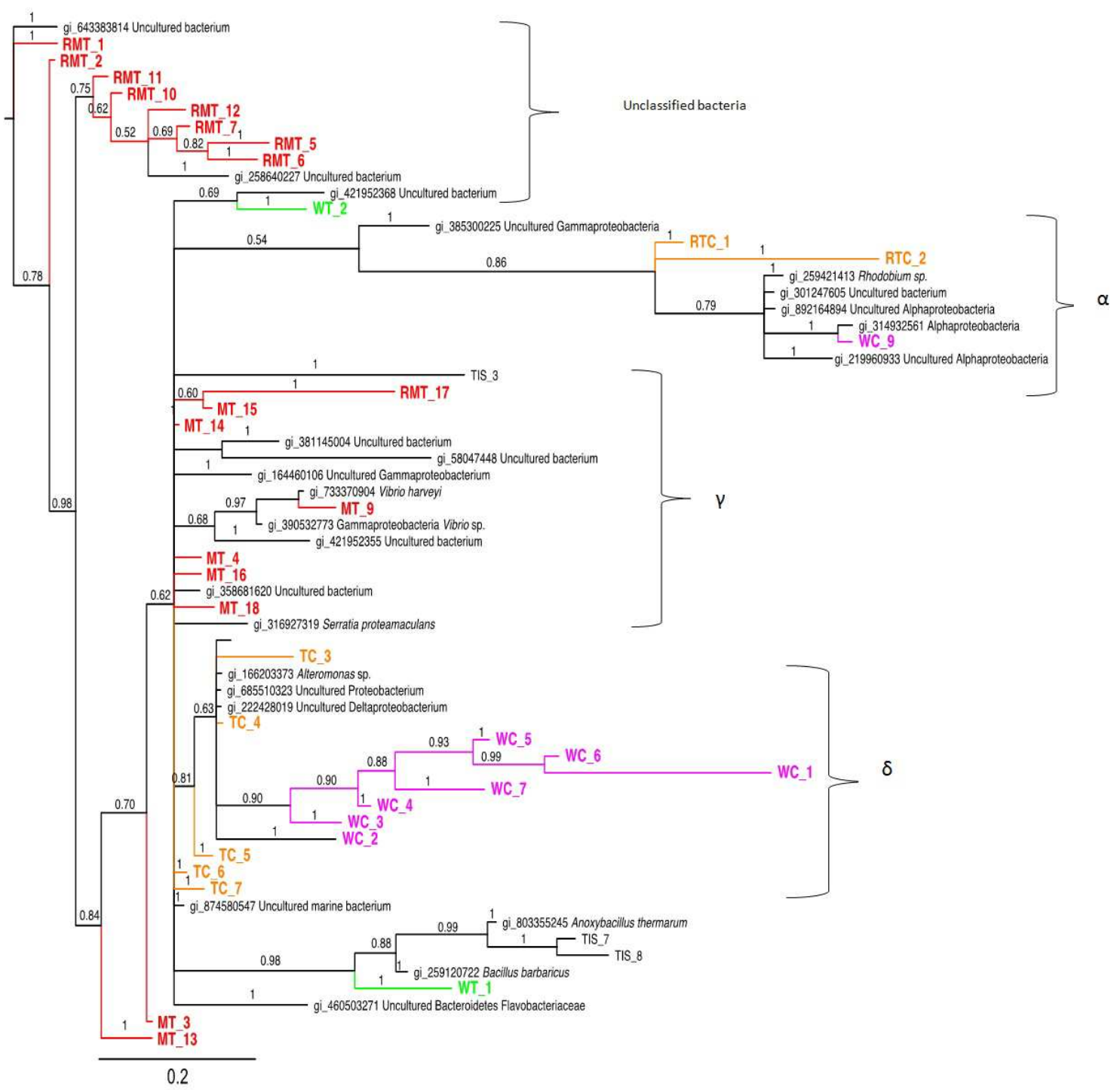

Figure 3. Denaturing gradient gel electrophoresis (DGGE) of the $16 S \mathrm{rRNA} V 3$ region in the coral tissue, mucus, and tank water analyzed after 10 days of thermal stress at $27 \pm 1^{\circ} \mathrm{C}$ versus $32 \pm^{\circ} \mathrm{C}$. Heirarchical clustering of $D G G E$ profiles was implemented on pvclust. Approximately unbiased p-values are shown in red and bootstrap probabilities are in green. 2 Sequencing of distinct DGGE bands reveal the diverse affiliation of bacteria associated with the coral. Colors in (2) represent the bands marked with colored circles in (1).

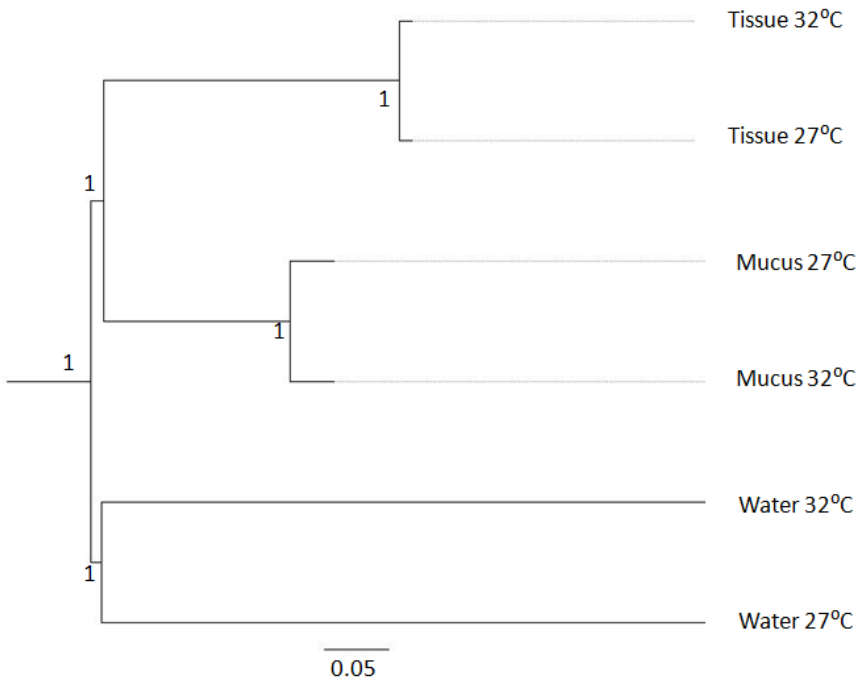

Figure 4. Cluster Analysis of sequences obtain from microbial community 16s rRNA (v4 region) gene. Cluster analysis was performed by cluster environment wiht thetayc values in a Unifrac metric analysis in mothur. The bar represent a weighted theytayc distance of 0.05 . 


\subsection{Diversity of nifH Sequences}

Clone libraries were prepared for the nifH gene sequences of mucus samples for both control and thermally stressed corals. Analysis of the nifH gene sequences obtained from the cloned isolates $(\mathrm{n}=150)$ showed diverse taxonomic membership. Both the Shannon and Simpson indices vividly indicated that microbial diversity is lower in the control and treated mucus samples compared to mucus collected from corals in situ (Table 1).

Table 1. Number of OTU and diversity estimates for nifH sequences from mucus samples of A. digitifera。

\begin{tabular}{llllllll}
\hline Library & $\begin{array}{l}\text { No. of clones } \\
\text { analyzed }\end{array}$ & $\begin{array}{l}\text { No. of OTU } \\
\text { observed }\end{array}$ & $\begin{array}{l}\text { ACE } \\
\text { estimator }\end{array}$ & $\begin{array}{l}\text { Chao } \\
\text { estimator }\end{array}$ & Simpson index & $\begin{array}{l}\text { Inverse } \\
\text { simpson }\end{array}$ & $\begin{array}{l}\text { Shannon } \\
\text { Alpha } \\
\text { Diversity }\end{array}$ \\
\hline $27^{\circ} \mathrm{C}$ & 50 & 32 & 48.85 & 48.8 & 0.7639 & 4.2353 & 2.626 \\
$32^{\circ} \mathrm{C}$ & 50 & 17 & 22.48 & 22.4 & 0.7975 & 1.5643 & 4.9388 \\
In-situ & 50 & 30 & 48.30 & 47.7 & 0.6844 & 2.718 \\
\hline
\end{tabular}

Meanwhile, non-parametric Chao and ACE estimators revealed that the species richness in mucus decreased in samples exposed to high temperature (Table 1). The findings validate the initial observation that artificial setting triggers shift in bacterial diversity of corals. Unfortunately, rarefaction curves based on OTUs did not reach saturation for all the samples (Figure 5b) thus, leads to an incomplete coverage of the nifH gene libraries and the sequencing of additional clones abruptly increases the number of discovered OTUs.

\subsection{Nitrogen Fixers in the Mucus Layer}

In-situ mucus derived sequences were taxonomically diverse with nearly half of the sequence belongs to Cyanobacteria (Figure 5a). Among the class of bacteria, cluster 11 with 24 sequences, proves to be the most abundant demonstrating a $100 \%$ amino acid identity with an uncultured member of Cyanobacteria in the genus Anabaena (NZ_KB235896.1) and with similar identity with filamentous cyanobacterium (NZ_KB904821.1) (Table 2).

Table 2. Abundant nitrogen fixing bacterial clusters associated with the Acropora digitifera mucus layer.

\begin{tabular}{|c|c|c|c|c|c|c|}
\hline \multirow{2}{*}{ Cluster } & \multirow{2}{*}{ Class } & \multirow{2}{*}{$\begin{array}{l}\text { Closest match in Blastn } \\
\text { (\% identity) Accession no. }\end{array}$} & \multirow{2}{*}{$\begin{array}{l}\text { No. of } \\
\text { clones }\end{array}$} & \multicolumn{3}{|c|}{ Abundance (\%) } \\
\hline & & & & Mucus $27^{\circ} \mathrm{C}$ & Mucus $32^{\circ} \mathrm{C}$ & Mucus in situ \\
\hline 1 & $\gamma$-Proteobacteria & Azotobacter (100) NC_012560.1 & 1 & 2 & -- & -- \\
\hline 2 & $\varepsilon$-Proteobacteria & Arcobacter(92) NC 017192.1 & 7 & 2 & 10 & 2 \\
\hline \multirow[t]{7}{*}{3} & $\gamma$-Proteobacteria & Rahnella (82) NC 016819.1 & 2 & -- & 4 & -- \\
\hline & & Tolumonas (84) NC_012691.1 & 3 & -- & -- & 6 \\
\hline & & Azotobacter (90) NC_ 012560.1 & 4 & 8 & -- & -- \\
\hline & & Teredinibacter(90) NC_ 012997.1 & 7 & 6 & 4 & 4 \\
\hline & & Methylomonas(84) NC_015572.1 & 1 & 2 & -- & -- \\
\hline & & Allochromatium(88) NC_013851.1 & 1 & -- & -- & 2 \\
\hline & & Marinobacterium(99) NZ_AUAZ01000022.1 & 2 & 4 & -- & -- \\
\hline \multirow[t]{2}{*}{4} & $\alpha$-Proteobacteria & Methylocystis(88) NC_018485.1 & 1 & 2 & -- & -- \\
\hline & & Bradyrhizobium (97) $\overline{\mathrm{N} C} \_017082.1$ & 2 & 4 & -- & -- \\
\hline \multirow[t]{6}{*}{5} & $\gamma$-Proteobacteria & Teredinibacter(89) NC 012997.1 & 6 & 4 & 8 & -- \\
\hline & & Azotobacter (91) NC_012560.1 & 12 & 8 & 16 & -- \\
\hline & & Pseudomonas (98) NC__009434.1 & 1 & 2 & -- & -- \\
\hline & & Dickeya(85) NZ_CM001857.1 & 2 & 2 & -- & 2 \\
\hline & & Vibrio(87) NZ_B̈BJY01000001.1 & 1 & -- & -- & 2 \\
\hline & & Tolumonas(88) NC 012691.1 & 1 & -- & -- & 2 \\
\hline \multirow[t]{2}{*}{6} & $\delta$-Proteobacteria & Desulfovibrio(89) $\bar{N} C \_016803.1$ & 8 & 6 & 8 & 2 \\
\hline & & Desulfomicrobium $(80) \mathrm{NZ}$ AUAR01000008.1 & 3 & -- & 6 & -- \\
\hline \multirow[t]{2}{*}{7} & $\delta$-Proteobacteria & Desulfobacter(84)NZ_JQKJ01000010.1 & 4 & 2 & 6 & -- \\
\hline & & Desulfobacterium(84) NC_012108.1 & 1 & -- & 2 & -- \\
\hline \multirow[t]{2}{*}{8} & $\delta$-Proteobacteria & Desulfomicrobium(80)NZ_AUAR01000008.1 & 1 & -- & 2 & -- \\
\hline & & Desulfovibrio(75) NC_016803.1 & 1 & -- & 2 & -- \\
\hline 9 & $\gamma$-Proteobacteria & Azotobacter (83) NC_012560.1 & 1 & -- & 2 & -- \\
\hline 10 & $\gamma$-Proteobacteria & Teredinibacter(86) NC__012997.1 & 1 & -- & 2 & -- \\
\hline \multirow[t]{9}{*}{11} & Cyanobacteria & Cyanothece(84) NC_011884.1 & 7 & 4 & 4 & 6 \\
\hline & & Filamentous cyanobacterium (86)NZ_KB904821.1 & 7 & -- & -- & 14 \\
\hline & & Microcoleus(84) NC_019738.1 & 1 & -- & -- & 2 \\
\hline & & Leptolyngbya (83) NZ_KB731324.1 & 1 & -- & -- & 2 \\
\hline & & Anabaena(100) NZ_KB- 235896.1 & 2 & -- & -- & 4 \\
\hline & & Rivularia(82) NC_019678.1 & 1 & -- & -- & 2 \\
\hline & & Calothrix(85) NZ_KB217478.1 & 1 & 2 & -- & -- \\
\hline & & Stanieria(95) NC_019748.1 & 1 & -- & -- & 2 \\
\hline & & Myxosarcina(89) NZ_JRFE01000060.1 & 3 & -- & -- & 6 \\
\hline 12 & $\delta$-Proteobacteria & Desulfovibrio(78)NZ_AUBQ01000013.1 & 2 & -- & -- & 4 \\
\hline
\end{tabular}




\begin{tabular}{|c|c|c|c|c|c|c|}
\hline \multirow{2}{*}{ Cluster } & \multirow{2}{*}{ Class } & \multirow{2}{*}{$\begin{array}{l}\text { Closest match in Blastn } \\
\text { (\% identity) Accession no. }\end{array}$} & \multirow{2}{*}{$\begin{array}{l}\text { No. of } \\
\text { clones }\end{array}$} & \multicolumn{3}{|c|}{ Abundance (\%) } \\
\hline & & & & Mucus $27^{\circ} \mathrm{C}$ & Mucus $32^{\circ} \mathrm{C}$ & Mucus in situ \\
\hline 13 & $\gamma$-Proteobacteria & Azotobacter(90) NC_012560.1 & 1 & -- & 2 & -- \\
\hline 14 & Cyanobacteria & Filamentous cyanobacterium (86)NZ_KB904821.1 & 1 & -- & -- & 2 \\
\hline \multirow[t]{3}{*}{15} & $\delta$-Proteobacteria & Desulfobacterium(84)NC_012108.1 & 1 & -- & 2 & -- \\
\hline & & Delsulfobacter(78) NZ_CM001488.1 & 1 & 2 & - & -- \\
\hline & & Desulfospira NZ_ATUḠ01000002.1 & 2 & -- & -- & 4 \\
\hline 16 & $\gamma$-Proteobacteria & Azotobacter(88) $\overline{\text { NC_}} 012560.1$ & 1 & -- & -- & 2 \\
\hline \multirow[t]{2}{*}{17} & $\beta$-Proteobacteria & Dechloromonas(94) $\overline{N C}_{-} 007298.1$ & 1 & -- & -- & 2 \\
\hline & & Burkholderia(78) NC_007952.1 & 1 & -- & -- & 2 \\
\hline 18 & $\gamma$-Proteobacteria & Halorhodospira(85) NC_008789.1 & 1 & -- & -- & 2 \\
\hline 19 & $\alpha$-Proteobacteria & Bradyrhizobium (97) NC__017082.1 & 1 & 2 & -- & -- \\
\hline 20 & $\gamma$-Proteobacteria & Azotobacter (91) NC_012560.1 & 10 & 4 & 10 & 6 \\
\hline 21 & $\delta$-Proteobacteria & Pelobacter(85) NC_007498.2 & 1 & -- & -- & 2 \\
\hline 22 & $\gamma$-Proteobacteria & Teredinibacter(88) NC_012997.1 & 1 & -- & 2 & -- \\
\hline 23 & $\gamma$-Proteobacteria & Azotobacter (86) NC_012560.1 & 1 & 2 & -- & -- \\
\hline 24 & $\gamma$-Proteobacteria & Methylomonas(84) NZ_BBCK01000057.1 & 1 & -- & -- & 2 \\
\hline 25 & $\delta$-Proteobacteria & Desulfobacter(88)NZ_JQKJ01000010.1 & 4 & -- & 6 & 2 \\
\hline 26 & Cyanobacteria & Filamentous cyanobacterium (86)NZ_KB904821.1 & 1 & -- & -- & 2 \\
\hline \multirow[t]{2}{*}{27} & $\alpha$-Proteobacteria & Methylocyctis(90) NC_018485.1 - & 1 & 2 & -- & -- \\
\hline & & Bradyrhizobium (97) NC_017082.1 & 2 & 4 & -- & -- \\
\hline 28 & $\alpha$-Proteobacteria & Xanthobacter(85) NZ_JAFO01000001.1 & 1 & 2 & -- & -- \\
\hline 29 & $\alpha$-Proteobacteria & Xanthobacter(89) NC_009720.1 & 1 & 2 & -- & -- \\
\hline 30 & $\beta$-Proteobacteria & Burkholderia(91) NC_007952.1 & 1 & -- & -- & 2 \\
\hline 31 & $\alpha$-Proteobacteria & Confluentimicrobium(90) NZ_CP010869.1 & 1 & 2 & -- & -- \\
\hline 32 & Cyanobacteia & Anabaena(84) NZ KB235896.1 & 3 & -- & -- & 6 \\
\hline 33 & Cyanobacteia & Cyanothece(82) NC_011729.1 & 1 & -- & -- & 2 \\
\hline 34 & $\gamma$-Proteobacteria & Halorhodospira(85) NC_008789.1 & 1 & 2 & -- & -- \\
\hline 35 & $\varepsilon$-Proteobacteria & Arcobacter(85) NC_017192.1 & 1 & 2 & -- & -- \\
\hline 36 & Bacteroidetes & Pedobacter(90) NZ_AWRU01000033.1 & 1 & 2 & -- & -- \\
\hline 37 & Cyanobacteria & Nostoc (83) NC_01-̄4248.1 & 1 & -- & 2 & -- \\
\hline 38 & Cyanobacteria & Stanieria(95) NC__019748.1 & 1 & 2 & -- & -- \\
\hline 39 & Unclassified bact. & Uncultured bacteria & 1 & 2 & -- & -- \\
\hline 40 & Unclassified bact. & Uncultured bacteria & 3 & 6 & -- & -- \\
\hline \multicolumn{3}{|c|}{ Total in 40 cluster } & 150 & 50 & 50 & 50 \\
\hline
\end{tabular}

Analysis is based on 150 sequences. A cluster is defined as nifH gene clones that have more than $75 \%$ sequence identity. The consensus sequence of the cluster was used in searching the Genbank Database (NCBI database using Blastn). nifH was only amplified from the mucus fractions (See Materials and Method).
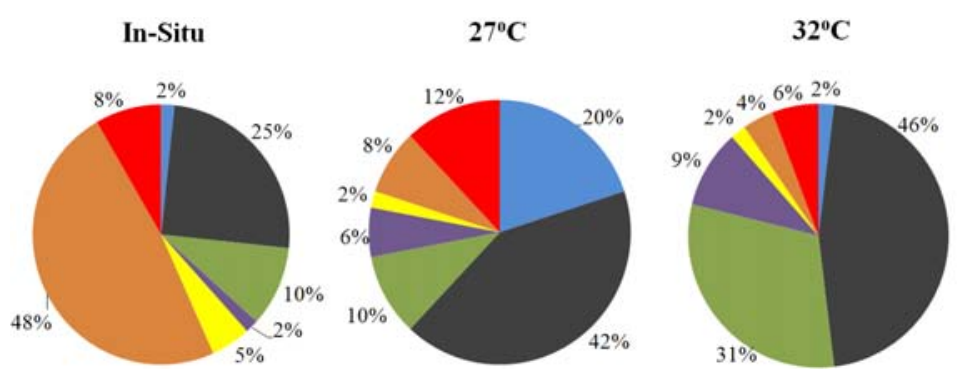

Alphaproteobacteria

- Gammaproteobacteria

Deltaproteobacteria

- Epsionproteobacteria

Betaproteobacteria

- Cyanobacteria

- Others

A.

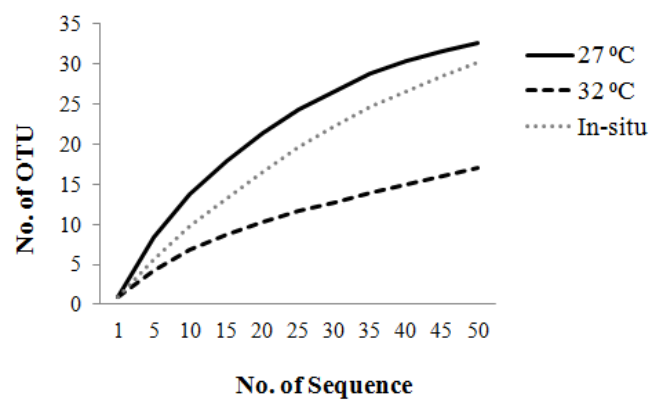

B.

Figure 5. Composition of nifH operational taxonomic units (OTU) from coral mucus. (A) Approximately 77-80\% of mucus nifH OTUs belong to Proteobacteria while about $13 \%$ belong to Cyanobacteria. A lower number of nifH OTUs were obtained from all the samples. Based on the rarefaction curve $(B)$, this is likely due to insufficient sample size. 
Similarity of sequence identity, roughly $95 \%$, was also observed in close homology to genus Staniera. Interestingly, a number of particular taxa was observed in the in-situ samples only, like the group of Aeromonadales and Oscillatorialles (Figure 6), as well as Betaproteobacteria. These sequence are affiliated with the group of Burkholderiales and Rhodocyclales, a group of symbiotic diazotrophs found in the root nodules of legume plant.

Among the remaining mucus-derived nifH sequences retrieved, 40 sequences was taken from uncultured member of Gammaproteobacteria, a close homology to Azotobacter with a perfect identity of $100 \%, 8$ sequences were found in the class of Epsilonproteobacteria and only one (1) belonged to the Bacteroidetes class.

Likewise, majority (77-80\%) of mucus nifH sequences belong to Proteobacteria, while Cyanobacteria was with $13 \%$ (Figure 5a). A wide distribution of Alphaproteobacteria across control samples was detected with close homology to the group of Rhizobiales (Xanthobacter, Methylocystis, Hyphomicrobium) and Rhodobacterales (Figure 6).

Remarkably, a number of the bacterial taxa that were observed in-situ samples were not detected in control samples, especially the group of Cyanobacria in the order Oscillatoriales. Meanwhile, bacterial class of Gammaproteobacteria, Epsilonproteobacteria and Deltaproteobacteria (Figure 5a), increases its frequency when exposed in the hatchery set-up. The finding clearly suggest that (1) artificial setting in the hatchery does not favor the above mentioned bacterial taxa, (2) either, the shift of bacterial composition affect the holobiont metabolism, (3) or corals manipulate the microbiota to adapt in the hatchery settings. Hence the increase of other bacterial taxa is favored for holobiont survival.

\subsection{Effect of Thermal Stress on the Nitrogen Fixing Bacterial Community}

Diazotrophic association in the treated $\left(32^{\circ} \mathrm{C}\right)$ mucus samples revealed a clear pattern of shift in bacterial communities. A spike increase in frequency was detected in the class Gammaproteobacteria specifically among Alteromonadales and Pseudomonadales group (Figure 6). Also, an increase was evident in the group of Epsilonproteobacteria which is closely similar to Campylobacterales. Furthermore, the same pattern was also observe in the group of Desulfovibrionales and Desulfobacterales (Figure 6) otherwise known as sulfate reducers.

On the other hand, the class of Cyanobacteria and Alphaproteobacteria, nifH sequences decreases in treated mucus samples relative to the control and In-situ samples (Figure 5a and 6). The findings confirms that elevated water temperature greatly affect the diazotrophic community and the coral survival.

\section{Discussion}

Corals take the majority of carbon requirement from their symbiotic associations with zooxanthellae $[41,59,64,65,66$,
88]. Typically, corals are passive suspension feeders which usually trap particles and bacteria in its mucus as a source of nutrients [21, 42, 71]. Besides being the direct source of nutrients to corals through bacterivory, a number of studies cite new evidences that microbial members of the coral holobiont potentially contribute fixed nitrogen to either the coral polyp or the zooxanthellae $[47,67]$.

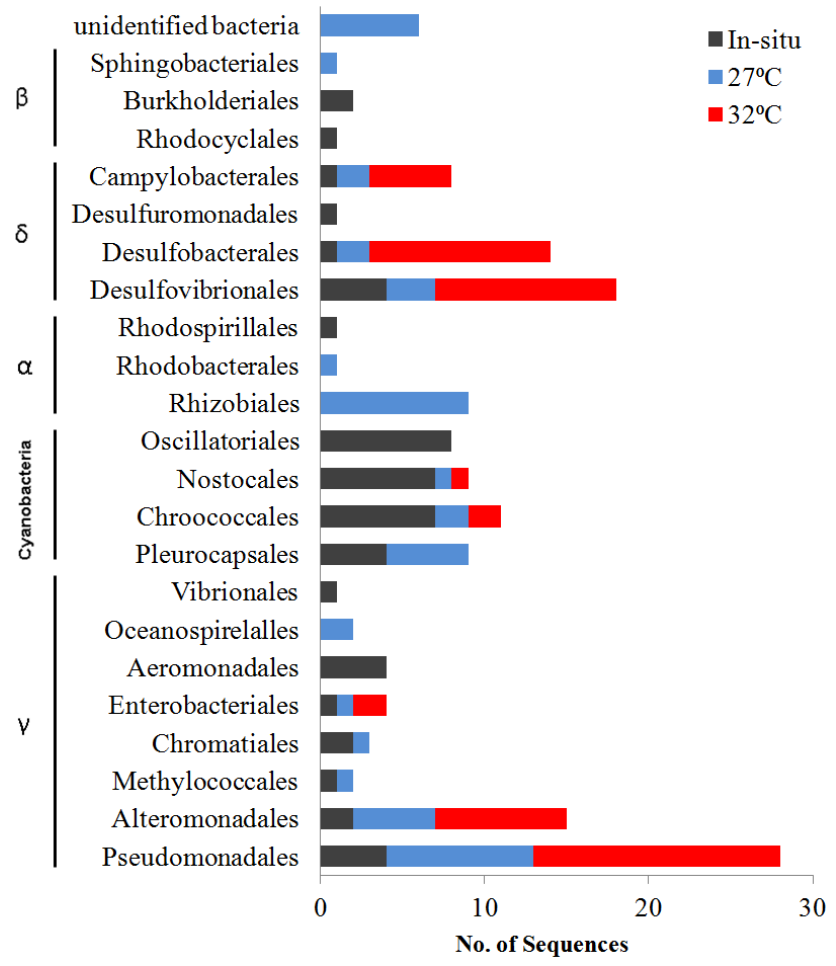

Figure 6. Bacterial taxa of associated nifH sequences from the coral mucus samples reveals shift in composition as expose to different environmental conditions. Control $\left(27^{\circ} \mathrm{C}\right)$, Treated $\left(32^{\circ} \mathrm{C}\right)$ and In-stu. Symbols represents each proteobacteria taxa; $(\gamma)$ gamaproteobacteria; $(\alpha)$ alphaproteobacteria; ( $\delta$ ) deltaproteobacteria; ( $\beta$ ) betaproteobacteria.

Lesser et al. [44], Ueda et al. [79] and Lema et al. [45, 46], reported that a large number of nitrogen fixing bacteria occurs in the coral mucus and tissue layer of Montastrea cavernosa. For instance, $V$. harveyi and $V$. alginolyticus both are capable of nitrogen fixation in coral mucus and dominate the culturable nitrogen fixing bacteria of the Brazilian coral Mussismilia hispida [10, 11]. Also, a comprehensive survey of nitrogen fixing bacteria recovered from mucus of three corals in Great Barrier Reef disclosed that the diversity of the nifH in mucus was generally similar to that of the surrounding seawater [81]. All these studies shows that nitrogen fixing bacteria is one of the component of the host microbiota to shape physiology of the coral when under stress circumstances.

The libraries derived from mucus samples of $A$. digitifera species during $10^{\text {th }}$ day thermal stress treatment reveals that diazotrophic communities are characterized by high diversity. Majority of the nifH sequences $(77 \%)$ retrieved from coral mucus belongs to Gammaproteobacteria class. Gammaproteobacteria groups is closely affiliated with 
Azotobacter and Teredinibacter. The former occurs as an intracellular endosymbiont in the gills of marine bivalves which provide host with enzyme including cellulases and nitrogenase critical for nitrogen deficiency [2, 18, 44, 84, 85]. While the latter, Azotobacter, is a free living diazotrophic bacteria with metabolic capabilities including atmospheric nitrogen fixation by conversion to ammonia and have a unique system of distinct nitrogenase enzyme [2, 35, 36, 37, 44, 54].

Obviously, bacteria plays a vital role in every ecosystem, enabling nitrogen to be made available for all organism. The ability to fix nitrogen is an important phenotypic trait of diazotrophic bacteria, and nifH has been use to distinguish representative at the clade level $[2,15,19]$. The findings of the study reveals that the domineering type of bacteria in the mucus of $A$. digitifera coral species is that of Gammaproteobacteria class. Much, the study indicates that ammonium is potentially abundant in coral mucus.

Meanwhile, majority of nifH sequences spotted were affiliated with the group of Cyanobacteria, regarded as main drivers of nitrogen fixation in corals $[20,44,65]$. Sequences retrieved were closely associated with Chroococales, Nostocales and Oscillatoriales. Cyanobacteria plays an essential role in modern coral reefs ecosystem being the major component of epiphytic, epilithic, and endolithic communities and of microbial mats as well $[26,50]$. In the microbial mats of reefs, Filamentous cyanobacterium strikingly dominates the ecosystem $[1,2,4,5,8]$. The diversity of cyanobacterial mats inhabiting different environments have been the focus of numerous studies on the several places such as: Tikehau atoll-French Polynasia [1, 66], in New Caledonia [8,9], and in the Western Indian Ocean in Zanzibar-Tanzania [4]. These studies identified different structures which differs in appearance [56], species composition, mode of growth and affiliation to the benthic organism including the coral and their substrate. Thus, these types of bacteria are vital during calcification and decalcification process $[8,9]$, much, in the stability of coralalgae symbosis [32, 33, 63, 76, 77].

A large number of nifH genes are closely related to sulfate reducers, including Desulfovibrionales and Desulfobacterales representing the second largest group retrieved from the mucus samples. Kimes and colleagues [37] determined that $22 \%$ of $d s r$ genes in corals belong to the Deltaproteobacteria subclass and indicated that inorganic sulfate is a potential source of sulfur for the corals holobiont. In a study that investigate nifH in corals, nifH sequences close to Desulfovibrio and other uncultured sulfate reducers were found [61]. And validating the findings of Olson and Colleagues [61], the study discovered nifH sequences affiliated with Desulfovibrio in the clone libraries for $A$. digitifera.

Interestingly, Alphatroteobacteria phylotypes which were closely related to bacterial species belonging to the Rhizobiales order were found in all mucus samples. Rhizobia are soil bacteria that inhabited nodules of legume plants roots [28, 45, 46]. Also, Rhizobia fix nitrogen, enabling plants to thrive and reproduce in nitrogen poor environments and in return of carbon and amino acid [22, 23, 43, 45, 46, 51].
In the desire to highlight the importance of Rhizobia group of bacteria, Rhizobium-affiliated sequences were clustered and was closely related to Bradyrhizobium, one of the most commonly occurring rhizobia that forms symbioses in the nodules of legumes plants. The study of Lema et al $[45,46]$ found a vertical transfer of diazotrophs from parental colonies of the Acropora millipora to their larvae, mostly an Alphaproteobacteria of the group Rhizobiales. The vertical transfer of diazotrophs further suggest a beneficial role of the group for holobiont functioning.

Furthermore, a number of nifH sequences were detected to be affiliated with Xanthobacter, a nutritionally versatile bacterium, with an unprecedented array of metabolic capability relevant in nitrogen fixation [52, 54]. Although the magnitude of transfer of fix nitrogen from diazotrophs into other compartments of the coral holobiont (e.g Symbiodinium) has not been quantified, recent studies shows that nitrogen fixation is a highly energy consuming process which requires $16 \mathrm{~mol}$ of ATP for the reduction of $1 \mathrm{~mol}$ of dinitrogen [54, 65]. Therefore, nitrogen fixation is energetically more costly than other mechanism of ammonium assimilation leading to the preference of other source of fixed nitrogen if available. Hence, nitrogen fixation serves as mechanism to counter act shortage of environmental nitrogen availability, and maintain a constant nitrogen supply for symbiotic based primary production in corals. These views is further supported by the findings of Olson [61] and Lesser [44] who reported a positive correlation of diazotrophs abundance with density and DNA content of Symbiodinium cells.

Despite the overall comparatively small contribution to the nitrogen budget of the coral holobiont, nitrogen fixation remains essential to the stability of the coral-algae symbiosis. If the ability of these marine diazotrophic bacteria to fix nitrogen in the association with the coral host is demonstrated experimentally, this will propel a deeper understanding of the evolution of nitrogen fixation and holobiont ecology. Consequently, it will constitute an important functional link between carbon and nitrogen fixation within the holobiont, and thus, contribute to the survival of corals in a highly oligotrophic reef environment.

Clearly, there is still much to learn about the diversity of nitrogen-fixing prokaryotes and their role in coral microbial communities, but our data suggest that nitrogen fixers associate with $A$. digitifera corals were diverse and may provide insight into the functional role of bacteria in support of the stress response of corals.

\section{Conclusion}

Taken together, the data indicated that nitrogen fixing bacteria exist in coral mucus and this layer paves the way to a diverse diazotrophic community. The specificity of mucus diazotrophs to each of the coral species provides support for the holobiont model of coral symbioses. Also, the overall consistency in the identification of diazotrophic nifH sequences associated with $A$. digitifera and from other corals 
suggest that these microbial groups is essential in nitrogen cycle within the coral holobiont. More importantly, changes in diazotrophic communities directly reflect shifts in environmental parameters, such as increase seawater temperature, and could be used to detect changes in coral fitness in response to environmental change.

\section{Conflict of Interest}

This study was funded by the University of the Philippines Marine Science Institute Biodiversity Conservation Grant and the DOST-SEI-ASTHRDP Scholarship Program. The authors declare no conflict of interest.

\section{Acknowledgements}

We thank the following, Dr. Wolfgang Reichardt and Ms Jacqueline Tabanera for a helpful critique and discussion. Dr. Cecilia Conaco for the construction of the study and to the Marine Molecular Biology Laboratory for the utmost support and provision of laboratory equipments and reagents. This study is funded by the DOST-SEI-ASTHRDP Scholarship Program and The UP Marine Science Institute Biodiversity Conservation Grant.

\section{References}

[1] Abed R, Al-Thukair A, Beer D. "Bacterial Diversity of Cyanobacterial mat degrading petroleum compounds at elevated salinities and temperatures". FEMS; Microbiol. Ecol. 2006. vol. 57: 290-301.

[2] Auman AJ, Speake CC, "Lidstrom ME. nifH sequences and nitrogen fixation in type I and type II methanotrophs," Appl. Environ. Microbiol, 2001. vol 67:4009-4016.

[3] Barott, K. L., and F. L. Rohwer. "Unseen players shape benthic competition on coral reefs". Trends Microbio 2012. vol 20:621-628.

[4] Bauer K, Díez B, Lugomela C, Seppala S, Borg A. J, and Bergman B. "Variability in benthic diazotrophy and cyanobacterial diversity in a tropical intertidal lagoon," FEMS Microbiol Ecol, 2008. vol 63:2, 205-221.

[5] Benson A, Muscatine L, "Wax in coral mucus-energy transfer from corals to reef fishes". Limnol Oceanogr, 1974, vol 19: 810-814.

[6] Canfield D, Glazer N, Falkowski P. "The evolution and future of earth's nitrogen cycle". Science 2010, vol 330:192-196.

[7] Capone, D. G., and E. J. Carpenter. "Nitrogen fixation in the marine environment". Science 1982: vol 217:1140-1142.

[8] Charpy L, Alliod R, Rodier M, and Golubic S, "Benthic nitrogen fixation in the SW New Caledonia lagoon, Aqua. Micro. Ecol," 2007, 47:1, 73-81.

[9] Charpy L, Palinska KA, Casareto B et al., "Dinitrogen-fixing cyanobacteria in microbial mats of two shallow coral reef ecosystems," Microbial Ecol 2010. vol 59:1, 174-186.

[10] Chimetto LA, Brocchi M, Thompson CC, Martins RCR, Ramos HR and Thompson FL. "Vibrios dominate as culturable nitrogen-fixing bacteria of the Brazilian coral Mussismilia hispida." Syst Appl Microbiol 2008. vol 31: 312319.

[11] Chimetto LA, Brocchi M, Gondo M, Thompson CC, GomezGil B, Thompson FL, "Genomic diversity of vibrios associated with the Brazilian coral Mussismilia hispida and its sympatric zoanthids (Palythoa caribaeorum, Palythoa variabilis and Zoanthus solanderi)". J Appl Microbiol 2009. vol 106; 1818-1826.

[12] Coffroth MA. Mucous sheet formation on poritid corals - an evaluation of coral mucus as a nutrient source on reefs. Mar Biol 1990. vol 105:39-49.

[13] Coles S, Strathman R. Observations on coral mucus flocs and their potential trophic significance. Limnol Oceanogr 1973. vol 18:673-678.

[14] Davey M, Holmes J, and Johnstone R. "High rates of nitrogen fixation (acetylene reduction) on coral skeleton following bleaching mortality". Coral reefs 2008. vol 27: 227-236. DOI10.1007/s00338-007-0316-9

[15] Dedysh, S. N., Ricke, P., Liesack, W. "NifH and NifD phylogenies: an evolutionary basis for understanding nitrogen fixation capabilities of methanotrophic bacteria". Microbiology 2004. vol 150: 1301-1313.

[16] Dekas A, Poretsky R, Orphan V. "Deep sea archae fix and share nitrogen in methyle consuming microbial consortia". Science 2009, vol 326: 422-426.

[17] Diez B, Alio CP, Marsh T, and Massanai R. "Application of Denaturing Gradient Gel Electrophoresis (DGGE) To study the diversity of marine picoeukaryotic assembleges and comparison of DGGE with other molecular techniques". Appl. Environ. Microbiol 2001. 67(7): 2942-295.

[18] Distel D., Morrill, W. MacLaren-Toussaint, N., Franks, D., Waterbury, J. "Teredinibacter turnerae gen. nov., sp. nov., a dinitrogen-fixing, cellulolytic, endosymbiotic gammaproteobacterium isolated from the gills of wood-bring molluscs". International Journal of Systematic and Evolutionary Microbiology 2002. vol 52: 2261-2269.

[19] Dobretsov, S., and P.-Y. Qien. "The role of epibiotic bacteria from the surface of the soft coral Dendronephthya sp. in the inhibition of larval settlement". J. Exp. Mar. Biol. Ecol. 2004. vol 299:35-50.

[20] Ferguson R. L., Buckley E. N. and Palumbo A. V. "Response of marine bacterioplankton to differential filtration and confinement". Appl. Environ. Microbiol 1984. vol 47, 49-55.

[21] Fitt, WK et al., "Response of two species of Indo pacific corals, Porites cylindrica and Stylophora pistillata to shortterm thermal stress: the host does matter in determining the tolerance of corals to bleaching". J Exp. Mar Biol. Ecol. 2009. vol 373; 102-110.

[22] Fred EB, Baldwin IL, McCoy E. Root nodule bacteria and leguminous plants, vol 5. Parallel Press, Madison, WI. 1992.

[23] Frieler, K., M. Meinshausen, A. Golly, M. Mengel, K. Lebek, S. D. Donner, et al. "Limiting global warming to 2 degrees $\mathrm{C}$ is unlikely to save most coral reefs". Nat. Clim. Change 2013. vol. 3:165-170.

[24] Garrard, S., R. Hunter, A. Frommel, A. Lane, J. Phillips, R. Cooper, et al. "Biological impacts of ocean acidification: a postgraduate perspective on research priorities". Mar. Biol. 2012. vol 160:1789-1805. 
[25] Gruber N. The Dynamic of marine nitrogen cycle and atmospheric $\mathrm{CO}_{2}$. T. Oguz and M. Follows, eds. Carbon Climate Interactions, Kluwer, Dordretch 2004. pp 97-148.

[26] Hagstrom A, Larsson U, Horstedt P, and Normark S. "Frequency of dividing cells. a new approach to the determination of bacterial growth rates in aquatic environments". Appl. Environ. Microbiol. 1979. vol 37:805812 .

[27] Harnik, P. G., H. K. Lotze, S. C. Anderson, Z. V. Finkel, S. Finnegan, D. R. Lindberg, et al. "Extinctions in ancient and modern seas". Trends Ecol. Evol. 2012. vol 27:608-617.

[28] Hennecke H, et al. "Concurrent evolution of nitrogenase genes and 16S rRNA in Rhizobium species and other nitrogen fixing bacteria". Arch. Microbiol. 1985. vol 142:342-348.

[29] Horn M, Wagner M. "Bacterial endosymbionts of free-living amoebae". J Eukaryot Microbiol. 2004. vol 51:509-514.

[30] Hoegh-Guldberg, O., P. Mumby, A. Hooten, R. Steneck, P. Greenfield, E. Gomez, et al. "Coral reefs under rapid climate change and ocean acidification". Science 2007. vol 318:17371742 .

[31] Hoegh-Guldberg, O. "Coral reef ecosystems and anthropogenic climate change". Reg. Environ. Change. 2011. vol 11:215-227.

[32] Holants J, Leroux O. Leliaert F, Decleyre H. De Cleck Oliver, Willems A. "Who is there? Exploration of Endophytic bacteria within the Siphonous Green seaweed Bryopsis (Bryopsidales, Chlorophyta)". Plos One 2011. 6(10); e26458.

[33] Huber JA, Welch DBM, Morrison GH, Huse SM, Neal PR, Butterfield DA, Sogin ML. "Microbial population structures in the deep marine biosphere". Science 2007. vol. 318:98-100.

[34] Hughes, T. P., Graham. NaJ, J. B. C. Jackson, P. J. Mumby, and R. S. Steneck. "Rising to the challenge of sustaining coral reef resilience". Trends Ecol. Evol. 2010. vol 25:633-642.

[35] Karl D, A. Michaels B, Bergmam D, et al. "Dinitrogen Fixation in the world's Ocean". Biogeochemistry 2002. vol 57:47-98.

[36] Kellogg CA, Lisle JT, and Galkiewicz JP. "Culture independent characterization of bacterial communities associated with the cold water coral Lophelia pertusa in the northeastern Gulf of Mexico". Appl. Environ. Microbiol. 2009. vol 75; 2294-2303.

[37] Kimes NE, Van Nostrand JD, Weil E, Zhou J, Morris PJ. "Microbial functional structure of Montastraea faveolata, an important Caribbean reef-building coral, differs between healthy and yellow-band diseased colonies". Environ Microbiol 2010. vol 12: 541-556.

[38] Kikuchi Y. "Endosymbiotic bacteria in insects: Their diversity and culturability". Microbes Environ. 2009. vol 24:195-204.

[39] Kleypas, J. A., and K. K. Yates. "Coral reefs and ocean acidification". Oceanography 2009. vol 22:108-117.

[40] Kneip C, Lockhart P, Vosz C, and Maeir G. "Nitrogen fixation in eukaryotes- new models for symbiosis". BMC Evol. Biol. 2007, pp 7:55.

[41] Koren O, Rosenberg E. "Bacteria associated with mucus and tissue of the coral Oculina patagonica in summer and winter". Appl. Environ. Microbiol 2006. vol 72(8):5254-5259.
[42] Krediet, C. J., K. B. Ritchie, V. J. Paul, and M. Teplitski. "Coral-associated micro-organisms and their roles in promoting coral health and thwarting diseases". Proc. Biol. Sci. 2013, 280:20122328.

[43] Lia CRS, Teixeira RS, Peixoto JC, Cury W, Jun S, Vivian H, Pellizari JT, Alexandre SR: "Bacterial diversity in rhizosphere soil from Antarctic vascular plants of Admiralty Bay, maritime Antarctica" ISME J 2010, vol 4: 989-1001.

[44] Lesser MP, Mazel CH, Gorbunav MY, Falkowski PG. "Discovery of symbiotic nitrogen fixing cyanobacteria in corals". Science, 2004, vol 305; 997-1000

[45] Lema, K. A., B. L. Willis, and D. G. Bourne. "Amplicon pyrosequencing reveals spatial and temporal consistency in diazotroph assemblages of the Acropora millepora microbiome". Environ. Microbiol 2014. Early View. doi:10.1111/ 1462-2920.12366.

[46] Lema AK, Willis BL, Bourne DG. "Corals form characteristic associations with symbiotic nitrogen fixing bacteria". Appl. Environ. Microbiol 2012. vol 78(9); 3136-3144

[47] Ladner JT, Palumbi SR, "Extensive sympatry, cryptic diversity and introgression throughout the geographic distribution of two coral species complexes". Mol. Ecol 2012. Vol 21, pp 2224-2238.

[48] Larkum, A. W. D. "High rates of nitrogen fixation on coral skeletons after predation by the crown of thorns starfish Acanthaster planci". Mar. Biol 1988. vol 97: pp 503-506.

[49] Larkum, A. W. D., I. R. Kennedy, and W. J. Muller. "Nitrogen fixation on a coral reef". Mar. Biol 1988. Vol 98: pp 143-155.

[50] López-Bueno A, Tamames J, Velázquez D, Moya A, Quesada A, Alcamí. A. "High diversity of the viral community from an Antarctic Lake". Science 2009, 326:858-861.

[51] Lodwig EM, et al. "Amino-acid cycling drives nitrogen fixation in the legume-Rhizobium symbiosis". Nature 2003. vol 422: 722-726.

[52] Malik KA, and Claus D. "Xanthobacter flavus, a new species of nitrogen fixing hydrogen bacteria". Int. J Systm Bacteriol 1979. vol 29(4); 283-287.

[53] Margulies M, Egholm M, Altman WE, et al: "Genome sequencing in microfabricated high- density picolitre reactors". Nature 2005, 437:376-380.

[54] Martensson L, Diez B, Wartiainen I, Zheng W et al., "Diazotrophic diversity, nifH gene expression and nitrogenase activity in a rice paddy field in Fujian China". Springer, Plant Soi 20091. DOI 10.1007/s11104-009-9970-8

[55] Marsden J, Meeuwig J. "Preferences of planktotrophic larvae of the tropical serpulid Spirobranchus giganteus (Pallas) for exudates of corals from a Barbados reef'. J Exp Mar Biol Ecol 1990. vol 137:97-104.

[56] Martensson L, Diez B, Wartiainen I, Zheng W et al., (2009). Diazotrophic diversity, nifH gene expression and nitrogenase activity in a rice paddy field in Fujian China. Springer, Plant Soil. DOI 10.1007/s11104-009-9970-8

[57] Mehta M, Butterfield D, Baross J, "Phylogenetic diversity of nitrogenase (nifH) genes in deep sea and hydrothermal vent environment of the juan de fuca ridge". Appl. Environ. Microbiol. 2003, pp 69: 960-970. 
[58] Meron, D., E. Atias, L. I. Kruh, H. Elifantz, D. Minz, M. Fine, et al. "The impact of reduced $\mathrm{pH}$ on the microbial community of the coral Acropora eurystoma". ISME J 2011. Vol 5:51-60.

[59] Middlebrook R, Hoegh-Guldberg O, Leggat W. "The effect of thermal history on the susceptibility of reef building corals to thermal stress". J Exp Biol 2008. Vo 1 211:1050-1056.

[60] Muyzer G and Smalla K. "Application of denaturing gradient gel eletrophoresis (DGGE) and temperature gradient gel eletrophoresis (TGGE) in microbial ecology". Acad. Pub. 1998. vol 73: 127-141.

[61] Olson ND, Ainsworth TD, Gates RD, Takabayashi M. "Diazotrophic bacteria associated with Hawaiian Montipora corals: diversity and abundance in correlation with symbiotic dinoflagellates". J Exp Mar Biol Ecol 2009. Vol 371: 140146.

[62] O’Neil, J. M., and D. G. Capone. "Nitrogen cycling in coral reef environments". pp. 949-989 in D. G. Capone, D. A. Bronk, M. R. Mulholland and E. J. Carpenter, eds. Nitrogen in the marine environment, 2nd ed. Academic Press, San Diego. 2008.

[63] Patton W. "Distribution and ecology of animals associ- ated with branching corals (Acropora spec.) from the Great Barrier Reef, Australia". Bull Mar Sci 1994. vol 55:193-211

[64] Pandolfi, J. M., S. R. Connolly, D. J. Marshall, and A. L. Cohen. "Projecting coral reef futures under global warming and ocean acidification". Science 2011. vol 333:418-422.

[65] Radecker N, Pogoreutz C, Voolstra C, Wiedenmann J, and Wild C. "Nitrogen cycling in corals: the key to understanding holobiont functioning". Trends in Microbiology August 2015, Vol. 23, No. 8.

[66] Raeid M. M Abed., Golubic S, Garcia-Pichel F, Camoin G. F, and Sprachta S. "Characterization of microbialite-forming cyanobacteria in a tropical lagoon: Tikehau Atoll, Tuamotu, French Polynesia," J of Phyco 2003, vol 39:5, 862-873.

[67] Rees, A. P. "Pressures on the marine environment and the changing climate of ocean biogeochemistry. Philos. Trans". A Math. Phys. Eng. Sci. 2012. vol 370:5613-5635.

[68] Ritchie KB, Smith GW. "Preferential carbon utilization by surface bacterial communities from water mass, normal, and white-band diseased Acropora cervicornis." Molecular Marine Biology and Biotechnology 1995. vol 4: 345-352.

[69] Ritchie KB, Smith GW. "Carbon-source utilization of coralassociated marine hetero- trophs". J Mar Biotechnol 1995a. pp 3:107-109.

[70] Ritchie KB, Smith GW. "Coral health and diseases". Springer: New York/Berlin" 2004

[71] Salihoglu, B., S. Neuer, S. Painting, R. Murtugudde, E. E. Hofmann, J. H. Steele, et al. "Bridging marine ecosystem and biogeochemistry research: lessons and recommendations from comparative studies". J. Mar. Syst. 2012. vol 109-110:161-175.

[72] Schloss PD. Westcott SL, Ryabin T, Hall JR, Hartman M. Hollister EB. Lesniewski RA, Oakley BB, Parks DH, Robinson CJ, Sahl JW, Stres B, Thallinger GG. Van Horn DJ, Weber CF. "Introducing mothur: open-source, platformindependent, community supported software for describing and comparing microbial communities". Appl. Environ. Microbiol 2009. Vol 75:7535-7541.
[73] Schloss PD. "Evaluating different approaches that test whether microbial communities have the same structure". The ISME J 2008. vol 2: 265-275.

[74] Schloss PD, Handelsman J. "Introducing DOTUR, a computer program for defining operational taxonomic units and estimating species richness". Appl Environ Microbiol 2005. vol 71: 1501-1506.

[75] Shannon CE \& Weaver W. "The Mathematical Theory of Communication". University of Illinois Press, Champaign, IL. Simpson EH. Measurement of Diversity. Nature 1994. pp 163:688.

[76] Stachowicz JJ, Hay ME. "Mutualism and coral persistence: the role of herbivore resistance to algal chemical defense". Ecology 1999. vol 80:2085-2101.

[77] Shinzato $\mathrm{C}$ et al. "Using the Acropora digitifera genome to understand coral response to environmental change". Nature 2011. vol 476: 320-323.

[78] Simpson, C. J., J. L. Cary, and R. J. Masini. "Destruction of corals and other reef animals by coral spawn slicks on Ningaloo Reef, Western Australia". Coral Reefs 1993. vol 12:185-191.

[79] Ueda T, Suga Y, Yahiro N, Matsuguchi T,. "Genetic diversity of N2-fixing bacteria associated with rice roots by molecular evolutionary analysis of nifD library". Can. J. Microbiol. 1995. vol 41:235-240.

[80] Ulisse Cardini, Vanessa N. Bednarz, Rachel A. Foster \& Christian Wild. "Benthic N2 fixation in coral reefs and the potential effects of human-induced environmental change". Eco. Evol. 2014. vol 4(9); 1706-1727.

[81] Williams WM, Viner AB, Broughton WJ,. "Nitrogen fixation (acetylene reduction) associated with the living coral Acropora variabilis." Mar Biol. 1987. vol 94: 531-535.

[82] Wilkinson, C. R., D. M. Williams, P. W. Sammarco, R. W. Hogg, and L. A. Trott. "Rates of nitrogen-fixation on coral reefs across the continental-shelf of the central Great Barrier Reef". Mar. Biol. 1984. vol 80:255-262.

[83] Winnepenninckx, B., Backeljau, T. and De Wachter, R. "Extraction of high molecular weight DNA from molluscs". TIG 1993. pp 9: 407.

[84] Yang JD, Worley E, Wang MY et al. "Natural variation for nutrient use and remobilization efficiencies in switchgrass". Bio Energy Res. 2009. vol 2:257-266.

[85] Yang CS et al. Endozoicomonas montiporae sp. nov. isolated from the encrusting pore coral Montipora aequituberculata. Int. J. Syst. Evol. Microbiol, 2010. vol 60; 1158-1162.

[86] Zehr JP, Jenkins BD, Short SM, Steward GF. Nitrogenase gene diversity and microbial community structure: acrosssystem comparison". Environ. Microbiol. 2003. vol 5:539554.

[87] Zehr JP, McReynolds LA. "Use of degenerate oligonucleotides for amplification of the nifH gene from the marine cyanobacterium Trichodesmium thiebautii." Appl. Environ. Microbiol. 1989. vol 55:2522-2526.

[88] Oliver TA, Palumbi SR. "Do fluctuating temperature environments elevate coral thermal tolerance?" Coral reef 2011. vol 30;429-440. 